Yaroslav Yanyshyn,

Ph.D., Associate professor, Lviv National Agrarian University, Ukraine

Halyna Bryk,

Ph.D., Associate professor, Lviv National Agrarian University, Ukraine

Yurij Kashuba,

Ph.D., Lviv National Agrarian University, Ukraine

\title{
PROBLEMS AND PERSPECTIVES OF INTERNET-INSURANCE IN UKRAINE
}

Abstract. The problems and prospects of insurance development in the internet are considered in the article. Considerable attention in the research is paid to the theoretical aspects of the essence of «internet insurance». The main stages of the insurance process through the internet and the key requirements that apply to the insurer and the insured when completing the insurance contract are described. It is determined that for the insurance company key advantages in the organization of virtual business are: lower costs associated with the organization of the company's website; lower transaction costs for customer service operations; expansion of geographical diversification of company insurance products; an opportunity to increase the sale of insurance products at the expense of open access to customers from around the world; customer service on a qualitatively new level - seven days a week, 365 days a year. The analysis of the insurance products market in the internet was conducted. The study found that insurance services offered through the internet in Ukraine include property, personal insurance and liability insurance. The most widespread in Ukraine are such insurance products as insurance for travelling abroad, medical insurance, CASCO, compulsory insurance of civil liability of owners of land vehicles, insurance of property of individuals, etc. The easiest procedure for purchasing a policy among all of these is auto insurance. The key attention is paid to ways of improving the mechanism of providing internet insurance. In the course of the study, specific directions for developing an ecommerce strategy for insurance companies based on SWOT-analysis were improved; developed an algorithm for strategic management of the insurance company and a conceptual model of interaction between the insurer and the insured in the framework of the process of strategic marketing planning in the market of internet services. An important role in the processes of management of the insurer was given to the complex of marketing communications, namely the elements of the marketing mix: "product», "price», "sales», "promotion». It is determined that for entering an insurance company into the market of internet services, the subject of planning is the outline of the main goals regarding sales and income received, as well as the definition of their potential consumers (market segment), the forming of their own image and reputation.

Keywords: internet insurance, insurer, on-line insurance, virtual economy, internet services.

Introduction. The globalization of economic processes and the development of the economy have radically changed the perceptions of modern business technologies. Thus, in recent years, the share of sales in the internet has been steadily increasing and reaching record-high rates. For many producers, the creation of its own virtual sales channel becomes a prerequisite for successful market operation and maximum efficiency in meeting the needs of consumers.

The practice of selling the internet has not exceded the scope of insurance. Using internet technology, insurers enter the market, bypassing the long and expensive process of creating traditional sales channels. This allows the insurance company to reduce the price of the insurance service, attract a significant number of customers and increase competitiveness.

Literature Review. The theoretical aspects of internet insurance are highlighted in the writings of both foreign and domestic authors. For example, Novak O. V. (2010) states that Internet-insurance is a complex of relationships between an insurance company and the customer arising from the sale of the insurance product, its service, and the payment of insurance indemnity when using Internet technologies as the most convenient, fast and cheap means of information exchange.

In turn, Naumenkova S. V. (2010) defines Internet-insurance as a process of interaction between an

Cite as: Yanyshyn, Y., Bryk, H. \& Kashuba, Y. (2019). Problems and Perspectives of Internet-Insurance in Ukraine. Marketing and Management of Innovations, 4, 31-38. http://doi.org/10.21272/mmi.2019.4-03 
insurance company and its clients, which consists in the choice of insurance services, the design and purchase of insurance policies and the receipt of insurance premiums using the Internet.

Spitsina N. M. (2017) understands by Internet insurance the interaction of interests between an insurance company and a customer arising from the sale of an insurance product and its service but produced using the Internet.

The overwhelming number of works on this topic were developed by foreign experts: G. Caprio, S. Kol, A. Demirgus Kant, I. Kirzner, A. Operkent. Their research is the basis for understanding the functioning of Internet acquisitions in individual countries, each characterized by the certain level of development of the financial services market and their own historical aspects of the functioning of Internet commerce.

The review of systems of Internet acquisition in foreign countries, conducted by resident scientists of these countries, allows tracing the regularities of functioning of Internet insurance systems on the basis of statistical, historical and political aspects. American researchers prefer data protection systems in already functioning complexes of Internet interaction. Western European scholars study the American experience and create their own model of functioning of Internet portals. In the writings of scholars from Eastern Europe, theoretical information about the implementation of Internet acquisition systems and consideration of foreign experience prevail.

Despite the number of research studies, this problem still needs to be explored regarding the possibilities of more efficient use of the internet to reach a wider range of potential consumers of insurance products.

Methodology and research methods. Internet insurance is one form of acquisition activity of an insurance company since the glut of classic channels of distribution of insurance service requires creation and development of new, more cost-effective and convenient mechanisms of interaction with clients. In order to comprehensively study the functioning and development of Internet insurance systems, it is necessary to refer to the economic essence of this concept and the principles of its organization. The current state of insurance market development is characterized by rapid automation of business processes and the transition to cloud and Internet technologies. The use of the Internet simultaneously facilitates the distribution of insurance products, their receipt by customers and reduces the cost of insurance company acquisition of insurance services. Reducing the cost of an e-commerce insurance company does not affect the quality of services and the customer receives the same set of economic benefits as in the traditional approach.

The transformation of the insurance market into high-tech structures is associated with the rapid growth in the number of Internet users, changes in the effective model of business processes construction, radical changes in the behaviour of individual consumers and the insurance segment as a whole.

Insurance as a financial service suitable for sale without direct contact between seller and buyer. First and foremost, this applies to those types of insurance that do not require the physical presence of the insurer's representative to assess the property interest to be insured. So, these are types of insurance with low insurance premiums, tariffs and insurance payments.

The comparison method was used to identify the features of online insurance, which allowed us to use different regional studies and get a complete picture of the phenomenon.

Using the method of statistical analysis, an analysis of the current state and tendencies of the functioning of Internet insurance was conducted, the method of graphical interpretation of the analyzed phenomena and processes was used to obtain the characteristics of the model of interaction between the insurer and clients during Internet insurance.

The theoretical and methodological basis of the research is the study of the peculiarities of insurance development under the conditions of the virtual economy and the development of practical recommendations for increasing the efficiency of internet insurance in Ukraine.

For the achievement of the set tasks the scientific methods of research are used: 
- induction and deduction - for substantiating the essential characteristics and deepening the concept of «internet insurance»;

- logical analysis - for generalizing the theoretical and practical aspects of providing insurance services in a virtual economy;

- economic and statistical methods - for processing data on the development of the internet insurance market:

- SWOT-analysis - for developing the insurance strategy for e-commerce;

- graphic methods - for graphical interpretation of the analyzed processes and to obtain the characteristics of the insurer and customer interaction model during online insurance.

The reporting of insurance companies using modern technologies to provide insurance services is often differentiated, which makes it impossible to fully evaluate the functioning of such a market mechanism. We believe that separating this information from the aggregate reports will contribute to both meetings the public's needs for access to information and will promote interest in the latest ways of acquiring insurance services.

On the basis of the conducted research, using the number of interpretation methods of the analyzed phenomena and processes, the results were summarized and predictions of future trends of development were made.

Results. The analysis of the insurance services market convincingly proves that today there is a need to reduce the cost of doing business for insurance companies and take effective measures to attract and retain customers. Thus, in the context of such measures, internet insurance plays an important role as an innovative form of virtual communication, which will improve the effectiveness of the insurance company.

In recent years, the proportion of sales in the internet is gradually increasing and reaching record levels, which affects the company's profits while reducing the cost of servicing the conclusion of transactions. For many insurance companies, the creation of its own virtual sales channel is a prerequisite for successful market operation and maximum efficiency in meeting the needs of its customer.

The number of potential users of virtual networks is constantly increasing from year to year, which confirms the important role of this channel for most companies when moving their products to potential customers.

In most cases, the internet uses socially active people with average and high purchasing power, that is, those that are of interest to the insurer. Using the internet, insurers can facilitate cooperation with consumers through more tight contacts, real-time communication, quick answers to the policyholder's questions. Significantly lower is the cost of advertising on the internet, which maximizes the reach of the target audience, which is a significant advantage for the insurance company.

The largest share of distance sales of life insurance services (through the internet, e-mail, call centres, etc.) is in Ireland (21\%), the Netherlands (11\%) and the United Kingdom (7\%). The similar situation is observed in the segment of risky types of insurance.

Creating the price comparison website allows a prospective client to access the offers of many insurer partners on a standard set of criteria in real-time. Despite the benefits of Internet insurance listed above, such channel for promotion of insurance products is not common among users in Ukraine. To confirm this, we have been tracking the popularity of google's search queries using tools like "Google Trends» (Figure 1).

As Figure 1 shows, an insufficient number of requests for «online insurance» is insufficient for graphs to be displayed, however, it nevertheless makes it possible to orient itself in the growing tendencies of interest in this area of insurance. However, it's too early to talk about growing user requests for the purchase of certain types of insurance products.

Many insurance companies (AXA Insurance, ASKA, Oranta, INGO Ukraine, Alfa Insurance, TAS, Universal) have regulated the sale of insurance products in the on-line mode. Insurance services offered 
through the internet in Ukraine include property, personal insurance and liability insurance. The most widespread insurance products in Ukraine, such as travel insurance abroad, medical insurance, CASCO, compulsory insurance of civil liability of owners of land vehicles, insurance of individuals' property, etc. The easiest procedure for purchasing a policy among all of these is auto insurance.

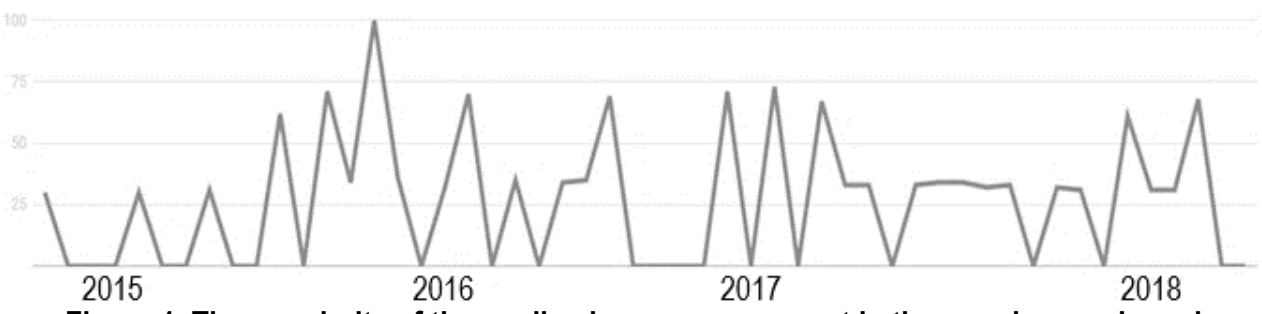

Figure 1. The popularity of the "online insurance» request in the google search engine Source: own research.

In the area of online insurance, some companies use mobile versions of the insurance portal and applications, which allows you to access the website through a smartphone or personal computer. The first such company was the insurance company VTB Insurance.

Information on using the Internet space by individual insurance companies of Ukraine is given in Table 1.

Table 1. Information on the use of Internet space by individual insurance companies of Ukraine

\begin{tabular}{|c|c|c|}
\hline Insurance company & $\begin{array}{c}\text { The number of requests per month } \\
\text { in the search engine «Google» }\end{array}$ & Internet resources \\
\hline ASKA & 325 & Facebook, PlayMarket \\
\hline ORANTA & 638 & Facebook \\
\hline PZU Ukraine & 444 & Facebook, YouTube, Instagram \\
\hline INGO Ukraine & 100 & Facebook, Google+, Twitter \\
\hline Universal & 572 & Facebook, Google+ \\
\hline TAS & 310 & Viber, Telegram, WhatsApp \\
\hline Alpha Insurance & 681 & Facebook, Viber \\
\hline Ukrainian insurance group & 271 & Facebook, Twitter, YouTube, Instagram \\
\hline «Провідна» & 207 & - \\
\hline
\end{tabular}

Source: own research.

The data in table 1 shows that Ukrainian insurance companies use various internet resources to inform potential consumers about their insurance products. In our opinion, it is quite justified to use the social network Facebook, Twitter, as well as mobile applications Viber, Instagram, PlayMarket, WhatsApp.

Consequently, for the future development of internet insurance, the insurance company's website should contain sufficient information content and the following opportunities should be provided to clients: the receipt of true information about the activities of the insurance company and its services; calculation of the cost of the insurance policy using an on-line calculator; filling in an application for insurance; in the case of insurance event the implementation of the distance payment of the insurance policy and insurance payments; delivery to the policyholder of the insurance policy, which would be confirmed by electronic signature; on-line communication with the client at all stages of the sale and servicing of the insurance contract. 
The new requirements for management of an insurance company are put forward in market economy conditions the strategy for organizing its activities should cover the elements of entrepreneurship and communication, which requires the implementation of the marketing strategy, along with the implementation of its plans for communication activities. Thus, in order to enter an insurance company in the market of internet services, the subject of planning is the outline of the main objectives of sales and revenue, as well as the definition of their potential consumers (market segment), the formation of their own image and reputation.

The procedure of strategic marketing planning as a complex of marketing actions, consisting of division of the market, the choice of the target segment, the development of options for a set of marketing measures and assessment of the insurance company.

The important role in the market of internet services for the rational organization of the insurance company's activity is to determine a clear sequence of actions by developing an algorithm for strategic management by an insurance company, which includes the following stages:

1. Development of the mission and general objectives of the insurance company.

2. Definition of the corporate strategy of the insurance company.

3. Development of a strategy for the business portfolio of an insurance company.

4. Development of strategic decisions for marketing («product», «price», «sale», «communication»).

5. Operative planning of decisions on each element of marketing of an insurance company.

6. Realization of complex measures.

7. Monitoring and evaluation of results.

On the basis of the given algorithm, the choice of strategy of the insurance company is of great importance. Considering the insurance company as a multi-level organization, one can determine that each level of management has its own strategies that require the use of planned actions for its development and implementation. For a top-level insurance company are possible growth strategies, portfolio strategies, and competitive strategies; at the tactical level - segmentation and positioning strategies; at the operational level - a specific set of marketing strategies-mix.

Thus, today's internet resources are an important tool for promoting insurance products, as well as a channel for selling insurance policies in Ukraine, the benefits of which benefits both insurance companies and insurers.

The most important advantage of using information technology for the insured is convenience and time-saving. The policyholder on the internet can independently choose insurance, make a calculation of the cost of the policy, compare it with similar offers from other companies, pay by any of the convenient ways and get a policy without leaving home.

The strategy of the development of e-commerce of the insurance company should take into account the criteria of market readiness, its operational capabilities and customer readiness, thus, on the basis of the SWOT-analysis, the strengths and weaknesses identified, as well as the threats and prospects of the insurance company in the market of Internet resources (Table 2).

Quickly and easily get a lot of information about the activities of insurers through the internet, their products, prices on it, which allows the consumer to simplify the process of selection. In turn, insurers can make permanent passive marketing research, study target markets, conduct survey of insurers, analyze the demand for insurance products and information about them, etc.

The development of internet marketing can reduce the cost of doing business by the insurance company, which is a significant advantage. When cooperating with a standard sales channel, the insurer must keep the office, office equipment, furniture, pay rent, etc. In turn, the organization of the virtual office has much lower costs, as well as the costs of entering into insurance contracts in the internet, are less than the cost of customer service in the office of the insurance company. Consequently, reducing the cost of doing business through internet marketing allows the insurer to increase its solvency and find time and 
resources to better serve their clients and to effectively control insurance cases. However, consumers usually prefer to buy insurance products through the office channel. Therefore, insurers should conduct additional research on the effectiveness of communication and the effectiveness of contact in the Internet network.

Table 2. SWOT-analysis of internet insurance services of the insurance company

\begin{tabular}{|c|c|}
\hline Strengths & Weaknesses \\
\hline $\begin{array}{ll}- & \text { convenience for customers; } \\
\text { - } & \text { saving time; } \\
\text { - } & \text { reduction of customer service costs; } \\
\text { - } & \text { expansion of territorial coverage of insurance products; } \\
- & \text { improvement of insurance culture; } \\
- & \text { reduction of the influence of the human factor; } \\
- & \text { discount system for insurance. }\end{array}$ & $\begin{array}{ll}- & \text { lack of strategic planning; } \\
- & \text { a large amount of information for its processing; } \\
- & \text { insufficient customer awareness; } \\
- & \text { imbalance of the insurance portfolio; } \\
- & \text { low level of capitalization; } \\
- & \text { low level of personnel qualification. }\end{array}$ \\
\hline Threats & Opportunities \\
\hline $\begin{array}{l}\text { - increased competition from domestic and foreign } \\
\text { companies; } \\
\text { - lack of trust of the population and enterprises in } \\
\text { insurance companies; } \\
-\quad \text { insecurity in the future; } \\
-\quad \text { strengthening of pressure and control by the legislation; } \\
\text { - } \quad \text { the unstable political situation in the country. }\end{array}$ & $\begin{array}{l}-\quad \text { market trend towards development; } \\
-\quad \text { expansion of the range of insurance company } \\
\text { services; } \\
-\quad \text { increase of efficiency of use of information } \\
\text { technologies; } \\
-\quad \text { creating opportunities for self-service; } \\
-\quad \text { legislative increase in the number of types of } \\
\text { compulsory insurance. }\end{array}$ \\
\hline
\end{tabular}

Source: own research.

Internet marketing enables consumers to be included in remote geographic regions, through which insurers can enter new segments, despite their financial ability to open branches in these regions.

According to the results of their own observations, it should be noted that today insufficient attention is paid to the systematic approach to using internet marketing tools by insurance companies.

Thus, for the successful organization of business activities in the internet, insurance companies need to give proper weight to the complex of marketing communications, namely the elements of the marketing mix: «product», «price», «sales», «promotion». In order to enter the insurance company in the market of internet services, the subject of planning is the outline of the main objectives of sales and revenue, as well as the definition of their potential consumers (market segment), the formation of their own image and reputation.

Conclusions. Today, for many producers the creation of its own virtual sales channel becomes a prerequisite for the successful functioning on the market and achieving maximum efficiency for meeting the needs of consumers. In the course of research, the strategies for developing e-commerce for insurance companies on the basis of SWOT-analysis were outlined; the algorithm for strategic management of the insurance company and the conceptual model of interaction between the insurer and the insured in the framework of the process of strategic marketing planning in the market of internet services were developed.

The further development of internet insurance in Ukraine at the state level requires clear legal regulation of the issue of electronic document circulation in civilian circulation; clarification of the status of paper copies of electronic documents (insurance contracts and policies); use of electronic digital signature; normative fixing of the status of users of electronic money; bringing the legislation on protection of consumer rights, protection of their personal data in accordance with acts of European legislation and others. 
Author Contributions. Conceptualization, Y. Y. and H. B.; methodology, H. B. and Y. K.; validation, Y. Y.; formal analysis, Y. Y. and H. B.; investigation, H. B. and Y. K.; resources, Y. Y. and Y. K.; data curation, H. B. and Y. K.; writing-original draft preparation, Y. Y. and H. B.; writing-review and editing, H. B. and Y. K.; visualization, H. B. and Y. K.; supervision, Y. Y.; project administration, Y. Y. and H. B.

\section{References}

Bashinskaya I.O. (2012). Marketing communications of the enterprise in social networks. Economic Sciences. Series «Economics and Management». 9 (34), Pages 36-41.

Bykov V.lu. (2012) Modern information technologies and innovative teaching methods in training of specialists: methodology, theory, experience, problems: Collection of scientific works. 29. Vinnytsia, Pages 32-40.

Dzina M.A. (2013). Interactive methods of insurance as a competitive advantage in the insurance market. Collection of scientific works of the Tavria State Agrotechnological University. «Economic sciences». 4 (24), Pages 61-63.

Karpenko N.V., Yalovegha N.I. (2012). Complex of marketing communications in the strategic management of marketing activity of the enterprise: monograph. Poltava: PUET.

Litovchenko I.L., Russkaya O.V., Novoshynska L.V., Baranova V.G. (2014). Strategic marketing planning in insurance companies: monograph of Odessa: INVVAC.

Mikhailovskaya I. M. (2015). Basic approaches to the definition of the essence, structure and principles of Internet insurance. Journal of the Khmelnitsky National University. 3 (3), Pages 157-160.

Naumenkova S.V., Mishchenko S. V. (2010). Financial Ambassador Market. Tutorial. K.: Knowledge.

Novak O.V. (2010). E-commerce. Tutorial. Alchevsk: DonSTU.

Polchanov A. Yu. (2015). Peculiarities of insurance development in conditions of Internet distribution. Journal of ZHDTU. 1 (71), Pages 256-260.

Prikazjuk N.V., Motashko T.P. (2014). The role of the Internet in the implementation of insurance services. Journal of the Taras Shevchenko National University. Series «Economics». 3 (156), Pages 45-52.

Sveshnikova K.T., Tyulin A.S. (2013). Perspectives of development of Internet insurance in Ukraine. Innovative economy. 5 (43), Pages 264-268.

Spitsyna N.M., Hryhorash O. V. Advantages and disadvantages of online insurance in Ukraine. Topical Issues of Modern Sciences 2017: Proceedings of the 1st International Scientific and Practical Conference. Poland: Stirred. Science and Research, 2017.http://www.rusnauka.com/12.APSN_2017/ Economics/20665.doc.

Ryabokon N.P. (2012). Systematization of sales channels of insurance products. Scientific Journal of the UBS NBU.34, Pages 268-275.

Ярослав Янишин, к.е.н., доцент, Львівський національний аграрний університет (Україна);

Галина Брик, к.е.н., доцент, Львівський національний аграрний університет (Україна);

Юрій Кашуба, к.е.н., Львівський національний аграрний університет (Україна).

Проблеми і перспективи інтернет-страхування в Україні

у статті розалянуто проблеми і перспективи розвитку страхування в мережі інтернет. Проаналізовано теоретичні підходи до визначення сутності «інтернет-страхування». Описано основні етапи процесу страхування через мережу інтернет та ключові вимоги, які ставляться до страховика і страхувальника при оформленні договору страхування. Визначено, що для страхової компанії ключовими перевагами в організації віртуального бізнесу є: менші витрати, пов'язані з організацією інтернет-сайту компанії; нижчі трансакційні витрати по операціям з обслуговування клієнтів; розширення географічної диверсифікації страхових продуктів компанії; можливість збільшення продажу страхових продуктів за рахунок відкритого доступу до клієнтів з різних країн світу; обслуговування клієнтів на якісно новому рівні - сім днів на тиждень, 365 днів в році. Проведено аналіз ринку страхових продуктів в мережі інтернет. Встановлено, що страхові послуги, які пропонують через мережу інтернет, в Україні включають майнове, особисте страхування та страхування відповідальності. Найбільш розповсюдженими в Україні є такі страхові продукти, як страхування подорожуючих за кордон, медичне страхування, КАСКО, обов'язкове страхування цивільно-правової відповідальності власників наземних транспортних засобів, страхування майна фізичних осіб тощо. Найбільш просту процедуру придбання полісу серед усіх перелічених має автострахування. Ключову увагу приділено шляхам вдосконалення механізму забезпечення інтернет-страхування. В работі запропоновані напрямки формування стратегії розвитку електронної комериії страхові компанії основі SWOT-аналізу; розроблено алгоритм стратегічного управлінням страховою компанією та концептуальну модель взаємодії страховика та страхувальника в рамках процесу стратегічного маркетингового планування на ринку інтернет-послуг. Важлива роль в процесах управління страховиком відводилася комплексу маркетингових комунікацій, а саме елементам маркетингу-міксу: «товар», «ціна», «збут», 
«просування». Визначено, що для входження страхової компанії на ринок інтернет-послуг предметом планування виступає окреслення основних цілей щодо обсягів продажу та отриманого доходу, а також визначення своїх потенційних споживачів (сегмента ринку), формування власного іміджу та репутації.

Ключові слова: інтернет-страхування, страховик, он-лайн страхування, віртуальна економіка, інтернет-послуги.

Manuscript received: 25.07.2019.

(C) The author(s) 2019. This article is published with open access at Sumy State University. 